\title{
UV Lighting in Horticulture: A Sustainable Tool for Improving Production Quality and Food Safety
}

\author{
Danilo Loconsole * (D) and Pietro Santamaria \\ Department of Agricultural and Environmental Science, University of Bari Aldo Moro, Via Amendola 165/A, \\ 70120 Bari, Italy; pietro.santamaria@uniba.it \\ * Correspondence: danilo.loconsole@uniba.it; Tel.: +39-080-544-30-39
}

check for

updates

Citation: Loconsole, D.; Santamaria, P. UV Lighting in Horticulture: A Sustainable Tool for Improving Production Quality and Food Safety. Horticulturae 2021, 7, 9. https:// doi.org/10.3390/horticulturae7010009

Received: 16 December 2020 Accepted: 15 January 2021 Published: 17 January 2021

Publisher's Note: MDPI stays neutral with regard to jurisdictional clai$\mathrm{ms}$ in published maps and institutional affiliations.

Copyright: (C) 2021 by the authors. Licensee MDPI, Basel, Switzerland. This article is an open access article distributed under the terms and conditions of the Creative Commons Attribution (CC BY) license (https:// creativecommons.org/licenses/by/ $4.0 /)$.

\begin{abstract}
Ultraviolet (UV) is a component of solar radiation that can be divided into three types defined by waveband: UV-A (315-400 nm), UV-B (280-315 nm), and UV-C (<280 nm). UV light can influence the physiological responses of plants. Wavelength, intensity, and exposure have a great impact on plant growth and quality. Interaction between plants and UV light is regulated by photoreceptors such as UV Resistance Locus 8 (UVR8) that enables acclimation to UV-B stress. Although UV in high doses is known to damage quality and production parameters, some studies show that UV in low doses may stimulate biomass accumulation and the synthesis of healthy compounds that mainly absorb UV. UV exposure is known to induce variations in plant architecture, important in ornamental crops, increasing their economic value. Abiotic stress induced by UV exposure increases resistance to insects and pathogens, and reduce postharvest quality depletion. This review highlights the role that UV may play in plant growth, quality, photomorphogenesis, and abiotic/biotic stress resistance.
\end{abstract}

Keywords: UV-A; UV-B; UV-C; ROS; LED; photomorphogenesis; phenols; postharvest

\section{Introduction}

Climate change, global water scarcity, and salinization have negatively affected arable land [1]. Global warming decreases production [2], while the demand for fresh highquality vegetables is increasing. Efficient artificial growing systems are essential to feed a human population in constant increase [3]. Greenhouse and indoor plant production systems produce clean fresh food, increasing yield and quality by controlling plant growth conditions. The latest technology in light emitting diode (LED) lighting is being adopted by farmers and allows broad control of spectra in the case of urban farming with fully artificial lighting. Spectrum modulation makes it possible to control growth and quality, including plant architecture, nutrient content, and phytochemical levels [4-7]. LED lighting can be used to complement natural daylight. Ultraviolet (UV) is part of the light spectrum, and can be divided into three types by waveband: UV-A (315-400 nm), UV-B (280-315 nm), and UV-C $(<280 \mathrm{~nm})$. UV-C and most UV-B is absorbed by the stratospheric ozone layer, whereas UV-A and a small part of UV-B reach the earth's surface and can be absorbed by plants. Although UV-B is the smallest component of sunlight $(<0.5 \%$ of the total energy reaching the surface), it has the highest energy and has a considerable impact on animals and plants [8].

UV light has a great impact on plant growth and quality, in relation to wavelength, intensity and exposure. Several studies have shown that high UV-A doses have a negative effect on PSII elaboration, decreasing maximum quantum efficiency, electron transport rate and photosynthesis due to a reduction in ribulose-1,5-bisphosphate carboxylase-oxygenase (RuBisCO) (C3 species) or PEP carboxylase (C4 species) and an increase in stomatal resistance and reactive oxygen species (ROS) production [9-13]. UV-B can induce abiotic stress and photomorphogenic changes. High UV-B exposure induces physiological stress, 
including ROS production, DNA deterioration and damage, and impairment of cell processes [14]. Low UV-B exposure promotes photomorphogenic changes, such as cotyledon expansion, biosynthesis of anthocyanins and flavonoids, inhibition of hypocotyl growth and stomatal opening $[8,15,16]$. Interaction between plants and UV light is regulated by photoreceptors, such as UV Resistance Locus 8 (UVR8), that allows acclimation to UV-B stress $[8,16,17]$. UVR8 is associated with the chromatin of UV-B-responsive genes, such as the promoter region of elongated hypocotyl 5 (HY5). UVR8 activity is also associated with the E3 ubiquitin ligase, known as constitutively photomorphogenic 1 (COP1). UVR8 interacts with COP1, and both are associated with photomorphogenic response [18].

Like UV-B, UV-C triggers stress responses in plants and may damage DNA and modify the functioning of chloroplasts and mitochondria [19-21]. Stressed plants may react by producing ROS. ROS signaling modifies physiological processes and produces secondary metabolites [21-23].

Exposure to UV also has a great impact on human health: the effects of UV radiation can manifest in the short and long term. Sunburn, tanning, and photosensitivity are the most common short-term effects [24]. Long term effects range from lentigines to melanocytic naevi, actinic keratosis and skin cancer [24]. Eyes can also be affected by UV exposure, manifesting as photokeratitis, cancer of the eye and cataract. Occupational exposure to UV should be kept to a minimum and protection should be always be worn. The risk can be drastically reduced by wearing appropriate closely woven clothing and a brimmed hat to reduce face and neck exposure. Sunscreen and eye protection (in relation to light type and intensity) are also advisable [24].

\section{UV Influence on Growth and Inhibition}

Although UV light is known to damage quality and production parameters, some studies show stimulatory effects of UV-A on biomass accumulation (roots and shoots) in certain species. The response of plants to UV radiation may be species-specific, ranging from stimulation to inhibition [25-29]. Among the studies that have shown species-specific effects of UV-A, promotion of biomass accumulation in roots was found in four Mediterranean species, including Laurus nobilis, grown with little irrigation [28,29]. This was attributed to improved efficiency of water use and increased photosynthesis rates, indicating that growth improvement was the result of UV and environmental factors. Changes in biomass allocation have also been linked to different allocation of resources [30]. This was reported in four cultivars of cucumber (Cucumis sativus) which showed a decrease in shoot biomass accumulation with no effects on roots after UV-A exposure [31]. Similar results were observed in Triticum sativum [32] and in four Arabidopsis thaliana ecotypes studied by Cooley et al. [26]. Negative effects of UV-A on shoot biomass were attributed to direct exposure of aerial parts to sunlight and it was argued that promotion of root growth was associated with UV-A photoreceptors in shoots, implicated in the transmission of long-distance signals that regulate root growth. Promotion of root growth by UV-A with no effects on shoots was also found in two cultivars of Glycine max under greenhouse conditions [33].

UV-B has also been found to affect growth. Several authors have reported a stimulatory effect of $4.15 \mu \mathrm{mol} \cdot \mathrm{m}^{-2} \cdot \mathrm{s}^{-1}$ UV-B [34,35] and $0.86 \mu \mathrm{mol} \cdot \mathrm{m}^{-2} \cdot \mathrm{s}^{-1}$ UV-B [35] on photosynthesis in cucumber seedlings. Other studies showed inhibition of hypocotyl elongation in cucumber [36,37], as well as promotion of stem diameter growth at medium intensity $\left(3.33 \mu \mathrm{mol} \cdot \mathrm{m}^{-2} \cdot \mathrm{s}^{-1} \mathrm{UV}-\mathrm{B}\right)$, without any damage, and a decrease in net photosynthesis at high intensity (5.54 or $6.67 \mu \mathrm{mol} \cdot \mathrm{m}^{-2} \cdot \mathrm{s}^{-1}$ ) [37]. In studies by Liu et al. [37], $3.33 \mu \mathrm{mol} \cdot \mathrm{m}^{-2} \cdot \mathrm{s}^{-1} \mathrm{UV}-\mathrm{B}$ promoted stem diameter growth, soluble sugar content, total ascorbic acid, and superoxide dismutase, peroxidase and catalase activities in cucumber leaves by $13.6-22.3 \%, 22.7-56.7 \%, 16.9-23.2 \%, 23.8-25.9 \%, 34.1-50.4 \%$ and $27.4-36.4 \%$, respectively, without compromising net photosynthesis rate.

Recent studies have evaluated the effects of UV-C on plant growth and photosynthesis. A positive effect of UV-C was found by Darras et al. [38] on 'Belladona F1' tomato 
(Solanum lycopersicum) plants. Irradiated with UV-C at $1.0 \mathrm{~kJ} \mathrm{~m}^{-2}$, the plants showed a $25 \%$ increase in total fruit number and a $36 \%$ increase in fruit weight compared to non-irradiated controls. A smaller increase was found with $2.5 \mathrm{~kJ} \cdot \mathrm{m}^{-2}$ ( $24 \%$ and $31 \%$, respectively). In the same experiment, UV-C was found to decrease plant height and net $\mathrm{CO}_{2}$ assimilation. Other evidence from the same experiment showed that pulsed UV-C irradiation induced changes in growth and fruit set in 'Belladonna F1' tomato plants. This higher yield of tomatoes may be due to shared UV-B photoreceptors also absorbing UV-C light [21], as occurs in some photomorphogenic reactions, promoting an increase in biomass [38].

Earlier experiments showed that pre-harvest UV-C irradiation induced flowering in certain ornamental plants [39-42]. In most cases there was no decrease in net $\mathrm{CO}_{2}$ assimilation between UV-C-irradiated plants and controls, which means no damage to PSII. Similar results were found in other species: chlorophyll fluorescence $(\mathrm{Fv} / \mathrm{Fm})$ of lettuce (Lactuca sativa) plants exposed to UV-C light was not reduced by doses up to $1.70 \mathrm{~kJ} \cdot \mathrm{m}^{-2}$, indicating no damage to PSII [43]. On the contrary, there was a significant decrease in net $\mathrm{CO}_{2}$ assimilation, stomatal conductance, $\mathrm{Fv} / \mathrm{Fm}$ and yield in strawberry (Fragaria $x$ ananassa Duch.) plants exposed to $1.5 \mathrm{~kJ} \cdot \mathrm{m}^{-2}$ every four days [44]. This means that effects may be species-specific.

\section{UV-Mediated Production of Healthy Compounds}

\subsection{Total Phenol Content}

Phenol compounds are secondary metabolites that are usually related to plant defense responses. Light plays an important role in several kinds of biotic and abiotic stimulation, triggering production of various phytochemicals (Figure 1). Several studies have shown that UV-A and UV-B signaling can both increase phenol content [45-47]. Studies on UV signaling have shown that UV-A and UV-B interact with different photoreceptors and/or mechanisms. The increase in phenol content mediated by UV-A was delayed in lettuce and Ixeris dentata with respect to the same response mediated by UV-B $[30,46,47]$. UV-B stress can increase the content of secondary metabolites useful for human health. For example, abiotic stress induced by exposure of mung bean sprouts to UV-B leads to significant accumulation of vitamin $C$, phenols and flavonoids, improving nutritional value [48]. These findings are in line with the results of experiments on buckwheat (Fagopyrum esculentum) sprouts [49], tomato [50], and Hypericum spp. [51]. Production of vitamin C, phenols and flavonoids in mung bean (Vigna radiata) sprouts may be promoted by low-dose irradiation with UV-B [48].

\subsection{Flavonoid Content}

Flavonoids are the major group of phenols related to responses to UV, and have a main antioxidant function [52]. Previous studies have established that flavonoids have UV-A and UV-B-absorbing properties. Most flavonoids absorb in the 315-400 nm UV-A range [53], playing an important role as antioxidants and protective compounds $[54,55]$. Several studies have shown that UV-A promotes accumulation of flavonols in Mesembryanthemum crystallinum [56]. Morales et al. [57] and Götz et al. [45] found that production was dose-dependent in Betula pendula and Arabidopsis thaliana, respectively. Besides light, other environmental factors modulate UV-A interactions with plants. For example, flavonoid levels in Pinus sylvestris, modulated by UV-A exposure, were enhanced under high, but not low nutrient availability. UV-A exposure decreased leaf content of quercetin derivatives in Arbutus unedo under low precipitation [58,59].

\subsection{Light-Absorbing Phenol Compounds}

Phenol compounds are an important group of phenylalanine-derived secondary metabolites with a wide range of properties, making them suitable for the food, pesticide, pharmaceutical and cosmetic industries [60]. Phenol compound biosynthesis in plants is regulated by UV-A [30] (Figure 1) and UV-B [60] radiation. Lighting dose may be modulated to maximize plant performance and accumulation of secondary metabolites [61]. 
Based on studies by Murthy et al. [62], UV-B stimulation of phenol compounds may be exploited in two steps: (i) plants are cultivated under optimal conditions until a determined growth stage; (ii) secondary metabolism is stimulated by UV-B to enhance phenol production. Species selection is essential as certain species may be naturally rich in secondary metabolites. For example, sweet basil (Ocimum basilicum L.), a member of the Lamiaceae family, accumulates high levels of different phenols, especially rosmarinic acid. These compounds can be used in the cosmetic, food and pesticide industries [63-65]. Several studies have shown that phenol production increased in sweet basil plants exposed to UV-B light $[66,67]$. Phenylalanine ammonia lyase (PAL) is the key enzyme of phenylpropanoid metabolism, triggering the biosynthesis of phenol compounds; several studies have shown that UV-B stress modulates an increase in PAL [68]. Mosadegh et al. [69] showed that plants treated with 34, 68 and $102 \mathrm{~kJ} \cdot \mathrm{m}^{-2}$. day ${ }^{-1} \mathrm{UV}$-B have enhanced production of phenols compared to controls, reaching the highest values at $102 \mathrm{~kJ} \cdot \mathrm{m}^{-2} \cdot \mathrm{day}^{-1}$. This could be due to a dose-dependent effect.

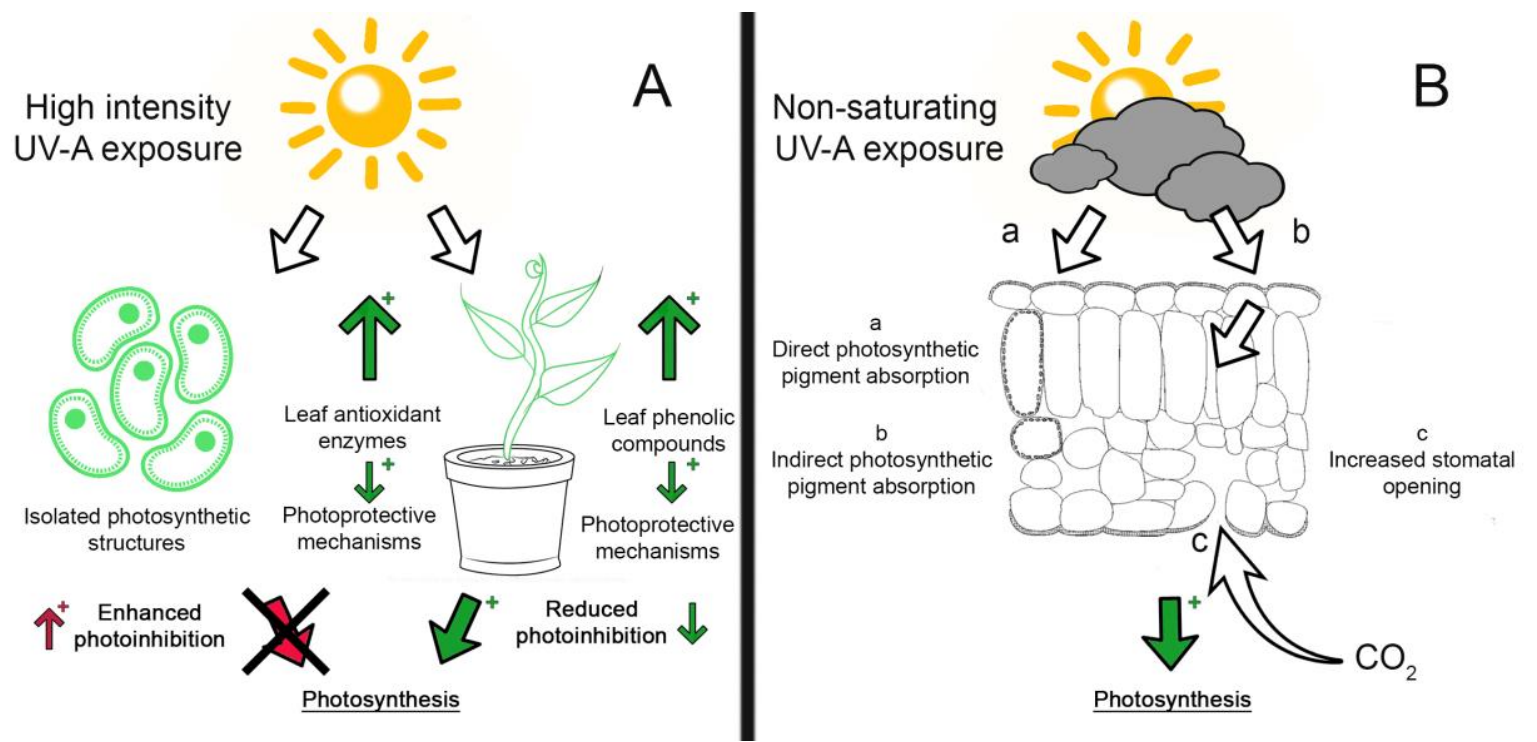

Figure 1. UV-A effects on photosynthesis. A plus (+) sign indicates enhanced response (either positive or negative); a green arrow indicates a positive response, and a red arrow indicates a negative response. (A) High intensity UV-A exposure enhanced photoinhibition in isolated photosynthetic structures (chloroplasts and thylakoids), whereas leaves exposed to UV-A activate photoprotective mechanisms (leaf phenols and antioxidant enzymes), reducing photoinhibition. (B) Under non-saturating light exposure, direct (a) or indirect (b) UV-A absorption by photosynthetic pigments induced blue-green fluorescence by phenols, and/or (c) increased stomatal opening, leading to enhanced photosynthesis rates [30].

\subsection{Carotenoid Production}

Different factors influence carotenoid production. Light interacts with phytochrome and/or UV-B receptors, regulating carotenoid accumulation [70], while ethylene modulates abiotic stress, including light stress [71]. Several studies report that UV-B radiation stimulates ethylene production in green tissues of many species, such as pear (Pyrus spp.) shoots, Arabidopsis, tobacco (Nicotiana spp.), and tomato [72-74], mediated by the ROS pathway. UV-B-mediated carotenogenesis is also influenced by genotype: indeed, different responses to UV-B exposure, related to endogenous ripening factors, have been described in different tomato genotypes $[75,76]$. Other studies found that carotenoid biosynthesis genes are generally down-regulated after chronic exposure to UV-B, but up-regulated after acute exposure to UV-B [77]. 


\subsection{Anthocyanin Content}

Anthocyanins are a major class of phenols with multiple health benefits. Lightmodulated anthocyanin production in plants has been studied by many authors, and UV light is known to play an important role in the anthocyanin biosynthesis pathway [78]. An experiment carried out by Su et al. [79] showed that UV-B at $5 \mathrm{~W} \mathrm{~m}^{-2}$ induced anthocyanin biosynthesis, with a time-dependent increase. This is in line with the findings of Solovchenko et al. [80] in apple (Malus domestica) skin, Wang et al. [78] in turnip (Brassica rapa) seedlings, and Tsurunaga et al. [49] in Triticum sprouts. Several studies have shown that PAL plays an important role in anthocyanin accumulation under UV-B irradiation [81,82]. When plants are exposed to a stressing environment, stored information is used to develop "memory" for future resistance [83]. This phenomenon was also observed for UV-B exposure: indeed, when light exposure was stopped, production of anthocyanin did not stop at the same time but continued to increase for more than six hours; the same was observed for PAL activity [79]. The above findings suggest that UV light enrichment can improve the nutritional quality of crops by enhancing production of healthy compounds. However, more research into the effects of UV treatment under closed conditions, such as in plant nurseries, is needed [47].

\section{UV Signaling for Photomorphogenesis}

Plant architecture is a key aspect for quality and production in horticulture. Dwarfed plant architecture is important for ornamental plants, increasing their economic value [84], especially at higher latitudes characterized by low light quality and quantity, where plants tend to elongate and the quality of production is low. Dwarfed architecture has advantages during transport, production and transplant and is less susceptible to damage [85]. More compact plants take up less space during transport and in transplant nurseries. Dwarfed plants, for example cucumber, produce the same number and size of fruit as non-dwarfed plants [85]. Saving space and reducing damage enables more sustainable production.

Traditionally, plant architecture was regulated using plant growth regulators (PGR), mechanical stimulation $[86,87]$ or irrigation deficits [88]. Instead, light can play an important role in dwarfing. Much work has been done on the influence of UV light on plant morphology, and plant response is not always the same but is species-dependent [89]. UV-B exposure has been found to lead to a decrease in foliar area, shoot dry mass and shoot length in some species [33,90-94], whereas in others, it leads to an increase in leaf area, fresh weight, and dry weight [95]. Although the effect of UV-B is variable and species-dependent, exposure generally increases the number of stems per tiller [93].

Comparisons of the effects of UV-A and UV-B exposure on cucumber show that plants exposed to UV-A and UV-B are both dwarfed, but plants exposed to UV-B lack a sturdy stem [85]. Stimulatory and inhibitory effects of UV-A and UV-B, respectively, were found in Arabidopsis. Supplementary exposure to UV-A led to a $30-150 \%$ increase in rosette diameter in eight accessions of $A$. thaliana grown indoors under low PAR conditions [96]. Additional supplementation with UV-B enhanced this phenotype. The same effect was observed under outdoor conditions. More studies showed that the UV-B dwarfing effect was higher than the stimulatory effects of UV-A on leaf size [96]. These findings suggest that UV light may be a sustainable alternative to chemical growth regulators for the production of dwarfed plants in horticulture [85].

\section{Biotic Resistance}

Plant exposure to solar UV-B radiation increases plant resistance to herbivorous insects and microbial pathogens [97]. The defense mechanism is regulated by JA-dependent and JA-independent pathways. This is supported by findings in Arabidopsis mutants with a deficiency in JA-signaling or insensitivity to JA, where UV-B had positive effects against Botrytis cinerea [97]. On the contrary, some plants such as a Nicotiana attenuata mutant silenced for a lipoxygenase (JA signaling pathway) gene, lost its defenses [98]. Besides jasmonate signaling, the photoreceptor UVR8 is also implicated in plant defense mechanisms 
mediated by UV-B light [99], promoting accumulation of sinapates [97], which are precursors of syringyl-type (defense) lignin synthesis. This mechanism prevents penetration of fungal hyphae by strengthening cell walls $[8,100]$. UV-B exposure also triggers indirect defense systems against insects by UVR8-controlled accumulation of flavonoids [8,101].

Due to its strong biological effect, UV radiation was observed to be effective in salt stress mitigation. Seed priming is a pre-sowing treatment which enables seeds to germinate more efficiently. Priming with UV-C light improved development of lettuce under stress conditions, increasing root and leaf dry weight in saline conditions [102]. Studies by Farhoudi et al. showed that the best result was reached at $0.85 \mathrm{~kJ} \cdot \mathrm{m}^{-2} \mathrm{UV}-\mathrm{C}$. UV-C priming allows more uniform growth under saline conditions [102]. It also reduces $\mathrm{Na}$ absorption and toxicity. UV-C presumably plays a role in the antagonistic relationship between $\mathrm{K}$ and $\mathrm{Na}$ [103]. Plants treated with a moderate dose of UV-C (Figure 2) showed higher phenol content and higher antiradical activity in the presence of $\mathrm{NaCl}$ [104].

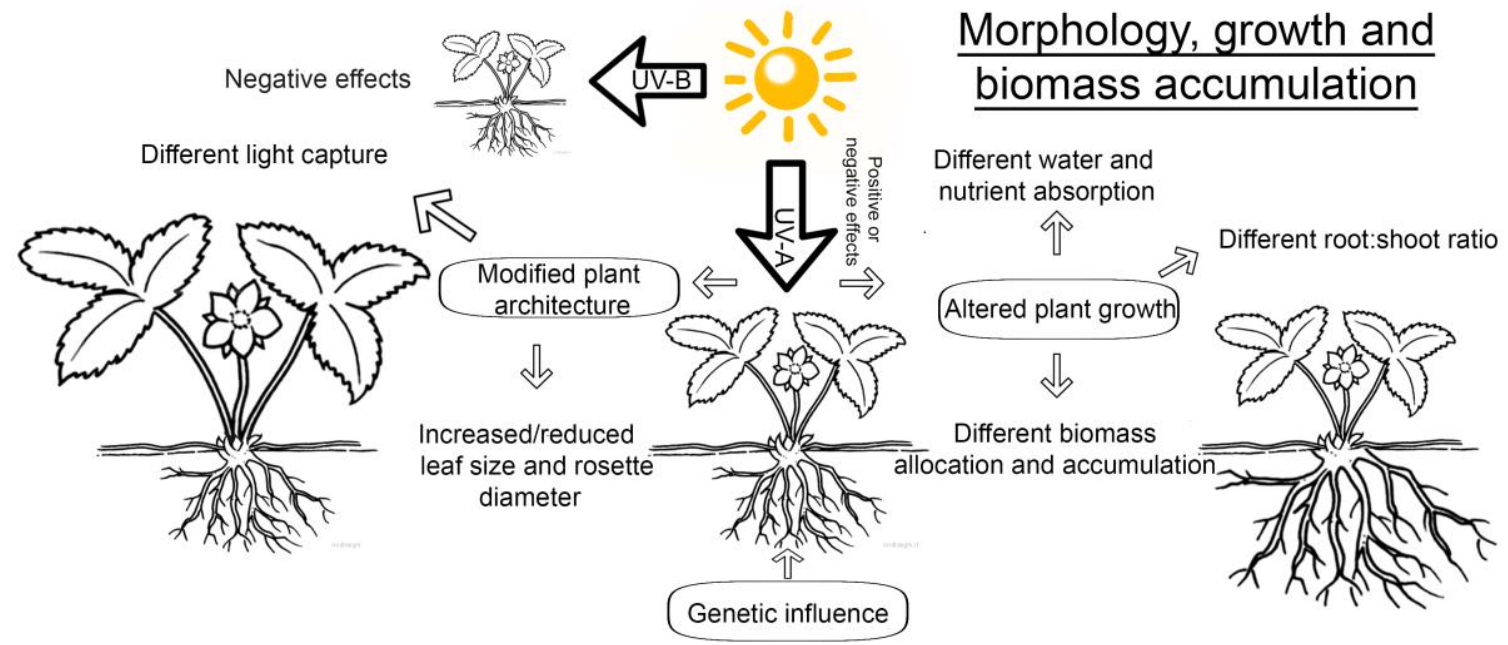

Figure 2. Plant morphological and biomass accumulation responses to UV. UV-A exposure has positive and negative effects on biomass accumulation and morphology, while UV-B effects are primarily negative. Changes in plant architecture and biomass allocation may influence resource uptake (light, water and nutrients). Changes mediated by UV-A may also depend on genetic and/or environmental factors [30].

\section{Postharvest and Storage}

\subsection{Postharvest Metabolic Processes Regulation}

In recent years, consumer concern for quality, nutraceutical characteristics and food security has grown. Globalization has led to trade on an international instead of a local scale. In this scenario, postharvest techniques become more important and sustainable cultivation is preferred to conventional methods. Modulation of light intensity and/or spectrum is promising due to its importance for metabolic processes such as biosynthesis of phytochemicals [50]. UV-B radiation may trigger accumulation of certain antioxidant molecules with a role in UV protection [105]. The results of treatment are plant species and dose-dependent. Plants treated with UV radiation develop mechanisms that protect them from stress. This protective stress response triggers changes in secondary metabolism, leading to accumulation of certain phytochemicals [106]. Research results indicate that UV-B radiation can be considered a sustainable new non-chemical way of slowing quality depletion in the postharvest storage, due to its capacity to enhance antioxidant activity, for example in tomato [107]. Similar results were found with UV-C in tomato, namely delay of ripening, improved firmness, and extended shelf life [108]. An experiment by Park and Kim [109] showed that $2.0 \mathrm{~kJ} \cdot \mathrm{m}^{-2} \mathrm{UV}-\mathrm{C}$ triggered the antioxidant pathway, increasing quercetin by $25 \%$ as well as flavonoid content. The highest quercetin level was found after 15 days of storage at $0{ }^{\circ} \mathrm{C}$. 


\subsection{Reduction of Microbial Population}

It has been demonstrated that postharvest UV application can be useful to reduce the microbial population, e.g., disinfection with non-ionizing UV-C. The main benefits are health security (absence of chemical residues) and low cost [110]. UV-C doses ranging from 0.5 to $20 \mathrm{~kJ} \cdot \mathrm{m}^{-2}$ were reported to limit microbial activity, inducing formation of pyrimidine dimers that alter the DNA helix, inhibiting microbial replication. Previous studies indicate that the effect of UV-C treatment was the same in the temperature range $5-37^{\circ} \mathrm{C}$ but may have been influenced by product surface and irradiation angle [111,112]. The microbial population may also be indirectly limited by plant defense mechanisms triggered by UV-C stress, delaying product deterioration. Abiotic stress conditions induced by treatment lead to activation of secondary metabolism, increasing production of phytochemicals with nutraceutical activity [113]. These effects have been observed for zucchini squash (Cucurbita pepo) [114], tomatoes [115], sweet potato (Ipomoea batatas) [116] and watermelon (Citrullus lanatus) [117]. In the same experiment carried out by Park and Kim [109], microbial population development was tested: garlic (Allium sativum) stored at $0{ }^{\circ} \mathrm{C}$ treated with $2 \mathrm{~kJ} \cdot \mathrm{m}^{-2} \mathrm{UV}-\mathrm{C}$ showed a reduction in microbial growth (3.82 log CFU) compared to control (4.86 log CFU) after 30 days storage. Other authors obtained similar results on fresh cut fruit and vegetables $[117,118]$. Several studies showed that UV-C light has a direct germicidal effect [117] and indirectly triggers the defensive phenol pathway [119].

\subsection{The Problem of Browning and PPO Inhibition}

Another postharvest problem is the browning of freshly cut vegetables [120]. Enzymic browning of fruit and vegetables takes place in the presence of oxygen when polyphenol substrates are exposed to polyphenol oxidase (PPO) and/or phenol peroxidase, as a consequence of brushing, peeling, cutting, and crushing during postharvest handling, which lead to a breakdown of cell structure [121]. Several studies have confirmed that UV-C can be useful as a PPO inhibitor in model systems, apple derivatives [122], fresh apple juice [123] and mushroom extracts [124]. Unfortunately, the potential for UV-C treatment is limited by possible adverse effects on food, including alteration of sensory quality attributes such as color [125]. Besides UV-C, UV-A has been found effective in PPO inhibition in several fruit $[123,125]$. The results showed that PPO was inactivated in fresh apple and pear juice by UV-visible treatment using a $400 \mathrm{~W}$ high-pressure mercury lamp for $120 \mathrm{~min}$. The lamps were placed $22.5 \mathrm{~cm}$ from the surface and had a spectrum between 250 and $740 \mathrm{~nm}$ and an incident energy of $3.88 \cdot 10^{-7} \mathrm{E} \cdot \mathrm{min}^{-1}$. UV-A LED treatment was also found effective in limiting color degradation of freshly cut apples by approximately $60 \%$ after $60 \mathrm{~min}$ exposure. The lamps emitted $9 \times 10^{-3} \mathrm{~kJ} \cdot \mathrm{m}^{-2}$. Unlike UV-C, UV-A controls browning without decreasing organoleptic and nutraceutical quality [120].

\section{Conclusions}

A lot of research has been conducted on the effects of ultraviolet radiation on plants and plant tissues. UV light has been found to be effective on plant growth, product quality, and photomorphogenesis. UV-A stimulated biomass accumulation improving efficiency of water use and photosynthesis rates, and UV-B promoted growth, photosynthesis, and stem diameter at medium intensity. UV-A and UV-B lead to significant accumulation of several secondary compounds such as vitamin C, phenols, and flavonoids with UV-protective properties, as well as chlorophyll, carotenoids, and anthocyanins. Plant architecture is a key aspect for quality and production in horticulture, and light can play an important role in dwarfing. Plant exposure to solar UV-B radiation increased plant resistance to herbivorous insects and microbial pathogens. In the globalized market of recent years, the importance of nutraceutical characteristics and food security is growing. Modulation of light intensity and/or spectrum is promising given its importance for postharvest metabolic processes. Research results indicated that UV-B radiation can be considered a sustainable new non-chemical way of slowing quality depletion in the postharvest storage. Moreover, UV application can be useful in reducing the microbial population. By contrast, 
little is known about interactions between light and other abiotic and biotic factors in relation to plant physiology and genetics. An important target for future studies may be to explain interactions between UV and other climatic factors in the search for new agricultural practices to improve the quality and healthiness of plant products, especially in greenhouses and urban plant factories.

Author Contributions: D.L.: drafting, bibliographic research and critical revision of the manuscript; P.S.: coordination of the work, drafting, and critical revision of the manuscript. All authors have read and agreed to the published version of the manuscript.

Funding: This review was funded by the Rural Development Programme of the Apulia Region (Italy) 2014-2020, Submeasure 16.2 (Support for pilot projects and development of new products, practices, processes and technologies, and transfer and dissemination of results obtained by Operational Groups), in the framework of the SOILLESS GO project (www.soilless.it), project code (CUP) B97H20000990009, paper n. 4.

Institutional Review Board Statement: Not applicable.

Informed Consent Statement: Not applicable.

Conflicts of Interest: The authors have no conflicts of interest to declare.

\section{References}

1. Loconsole, D.; Murillo-Amador, B.; Cristiano, G.; De Lucia, B. Halophyte common ice plants: A future solution to arable land salinization. Sustainability 2019, 11, 6076. [CrossRef]

2. Okayama, T.; Okamura, K.; Park, J.-E.; Ushada, M.; Murase, H. A simulation for precision airflow control using multi-fan in a plant factory. Environ. Control Biol. 2008, 46, 183-194. [CrossRef]

3. Darko, E.; Heydarizadeh, P.; Schoefs, B.; Sabzalian, M.R. Photosynthesis under artificial light: The shift in primary and secondary metabolism. Philos. Trans. R. Soc. B Biol. Sci. 2014, 369, 20130243. [CrossRef] [PubMed]

4. Ouzounis, T.; Rosenqvist, E.; Ottosen, C.-O. Spectral effects of artificial light on plant physiology and Secondary Metabolism: A review. HortScience 2015, 50, 1128-1135. [CrossRef]

5. Hytönen, T.; Pinho, P.; Rantanen, M.; Kariluoto, S.; Lampi, A.; Edelmann, M.; Joensuu, K.; Kauste, K.; Mouhu, K.; Piironen, V.; et al. Effects of LED light spectra on lettuce growth and nutritional composition. Light. Res. Technol. 2018, 50, 880-893. [CrossRef]

6. Pawłowska, B.; Żupnik, M.; Szewczyk-Taranek, B.; Cioć, M. Impact of LED light sources on morphogenesis and levels of photosynthetic pigments in Gerbera jamesonii grown in vitro. Hortic. Environ. Biotechnol. 2018, 59, 115-123. [CrossRef]

7. Joshi, N.C.; Ratner, K.; Eidelman, O.; Bednarczyk, D.; Zur, N.; Many, Y.; Shahak, Y.; Aviv-Sharon, E.; Achiam, M.; Gilad, Z.; et al. Effects of daytime intra-canopy LED illumination on photosynthesis and productivity of bell pepper grown in protected cultivation. Sci. Hortic. (Amst.) 2019, 250, 81-88. [CrossRef]

8. Jenkins, G.I. Signal Transduction in responses to UV-B radiation. Annu. Rev. Plant Biol. 2009, 60, 407-431. [CrossRef]

9. Vass, I.; Turcsányi, E.; Touloupakis, E.; Ghanotakis, D.; Petrouleas, V. The mechanism of UV-A radiation-induced inhibition of photosystem II electron transport studied by EPR and chlorophyll fluorescence. Biochemistry 2002, 41, 10200-10208. [CrossRef]

10. Prado, F.E.; Rosa, M.; Prado, C.; Podazza, G.; Interdonato, R.; González, J.A.; Hilal, M. UV-B radiation, its effects and defense mechanisms in terrestrial plants. In Environmental Adaptations and Stress Tolerance of Plants in the Era of Climate Change; Springer: New York, NY, USA, 2012; pp. 57-83; ISBN 9781461408154.

11. Takahashi, S.; Badger, M.R. Photoprotection in plants: A new light on photosystem II damage. Trends Plant Sci. 2011, 16, 53-60. [CrossRef]

12. Nawkar, G.; Maibam, P.; Park, J.; Sahi, V.; Lee, S.; Kang, C. UV-induced cell death in plants. Int. J. Mol. Sci. 2013, 14, 1608-1628. [CrossRef] [PubMed]

13. Kosobryukhov, A.A.; Lyubimov, V.Y.; Kreslavski, V.D. Adaptive mechanisms of photosynthetic apparatus to UV radiation. In Stress Responses in Plants; Springer International Publishing: Cham, Switzerland, 2015; pp. 59-78. ISBN 9783319133683.

14. Heijde, M.; Ulm, R. UV-B photoreceptor-mediated signalling in plants. Trends Plant Sci. 2012, 17, 230-237. [CrossRef] [PubMed]

15. Kim, B.C.; Tennessen, D.J.; Last, R.L. UV-B-induced photomorphogenesis in Arabidopsis thaliana. Plant J. 1998, 15, 667-674. [CrossRef] [PubMed]

16. Ulm, R.; Nagy, F. Signalling and gene regulation in response to ultraviolet light. Curr. Opin. Plant Biol. 2005, 8, 477-482. [CrossRef] [PubMed]

17. Rizzini, L.; Favory, J.-J.; Cloix, C.; Faggionato, D.; O’Hara, A.; Kaiserli, E.; Baumeister, R.; Schafer, E.; Nagy, F.; Jenkins, G.I.; et al. Perception of UV-B by the Arabidopsis UVR8 protein. Science 2011, 332, 103-106. [CrossRef]

18. Favory, J.J.; Stec, A.; Gruber, H.; Rizzini, L.; Oravecz, A.; Funk, M.; Albert, A.; Cloix, C.; Jenkins, G.I.; Oakeley, E.J.; et al. Interaction of COP1 and UVR8 regulates UV-B-induced photomorphogenesis and stress acclimation in Arabidopsis. EMBO J. 2009, 28, 591-601. [CrossRef] [PubMed] 
19. Balestrazzi, A.; Locato, V.; Bottone, M.G.; De Gara, L.; Biggiogera, M.; Pellicciari, C.; Botti, S.; Di Gesù, D.; Donà, M.; Carbonera, D. Response to UV-C radiation in topo I-deficient carrot cells with low ascorbate levels. J. Exp. Bot. 2010, 61, 575-585. [CrossRef]

20. Saxena, S.; Joshi, P.; Grimm, B.; Arora, S. Alleviation of ultraviolet-C-induced oxidative damage through overexpression of cytosolic ascorbate peroxidase. Biologia 2011, 66, 1052. [CrossRef]

21. Urban, L.; Sari, D.C.; Orsal, B.; Lopes, M.; Miranda, R.; Aarrouf, J. UV-C light and pulsed light as alternatives to chemical and biological elicitors for stimulating plant natural defenses against fungal diseases. Sci. Hortic. (Amst.) 2018, 235, 452-459. [CrossRef]

22. Suzuki, N.; Mittler, R. Reactive oxygen species and temperature stresses: A delicate balance between signaling and destruction. Physiol. Plant. 2006, 126, 45-51. [CrossRef]

23. Urban, L.; Charles, F.; de Miranda, M.R.A.; Aarrouf, J. Understanding the physiological effects of UV-C light and exploiting its agronomic potential before and after harvest. Plant Physiol. Biochem. 2016, 105, 1-11. [CrossRef] [PubMed]

24. World Health Organization. Protection against Exposure to Ultraviolet Radiation; World Health Organization: Geneva, Switzerland, 2001.

25. Tezuka, T.; Hotta, T.; Watanabe, I. Growth promotion of tomato and radish plants by solar UV radiation reaching the Earth's surface. J. Photochem. Photobiol. B Biol. 1993, 19, 61-66. [CrossRef]

26. Cooley, N.; Higgins, J.; Holmes, M.; Attridge, T. Ecotypic differences in responses of Arabidopsis thaliana L. to elevated polychromatic UV-A and UV-B+A radiation in the natural environment: A positive correlation between UV-B+A inhibition and growth rate. J. Photochem. Photobiol. B Biol. 2001, 60, 143-150. [CrossRef]

27. Kataria, S.; Guruprasad, K.N.; Ahuja, S.; Singh, B. Enhancement of growth, photosynthetic performance and yield by exclusion of ambient UV components in C3 and C4 plants. J. Photochem. Photobiol. B Biol. 2013, 127, 140-152. [CrossRef] [PubMed]

28. Bernal, M.; Llorens, L.; Badosa, J.; Verdaguer, D. Interactive effects of UV radiation and water availability on seedlings of six woody Mediterranean species. Physiol. Plant. 2013, 147, 234-247. [CrossRef]

29. Bernal, M.; Verdaguer, D.; Badosa, J.; Abadía, A.; Llusià, J.; Peñuelas, J.; Núñez-Olivera, E.; Llorens, L. Effects of enhanced UV radiation and water availability on performance, biomass production and photoprotective mechanisms of Laurus nobilis seedlings. Environ. Exp. Bot. 2015, 109, 264-275. [CrossRef]

30. Verdaguer, D.; Jansen, M.A.K.; Llorens, L.; Morales, L.O.; Neugart, S. UV-A radiation effects on higher plants: Exploring the known unknown. Plant Sci. 2017, 255, 72-81. [CrossRef]

31. Krizek, D.T.; Mirecki, R.M.; Britz, S.J. Inhibitory effects of ambient levels of solar UV-A and UV-B radiation on growth of cucumber. Physiol. Plantarum. 1997, 100, 886-893. [CrossRef]

32. Häder, D.P. Effects of solar radiation on local and German wheat seedlings in a Chilean high mountain station. J. Photochem. Photobiol. B Biol. 1996, 35, 181-187. [CrossRef]

33. Zhang, L.; Allen, L.H.; Vaughan, M.M.; Hauser, B.A.; Boote, K.J. Solar ultraviolet radiation exclusion increases soybean internode lengths and plant height. Agric. For. Meteorol. 2014, 184, 170-178. [CrossRef]

34. Hou, F.J.; Ben, G.Y. Effect of UV-B radiation on physiological properties in soybean and cucumber seedlings. Chin. J. Appl. Environ. Biol. 1999, 5, 455-458.

35. Sun, L.H.; Li, Z.H.; Duan, L.S.; Wei, Z.G.; Wang, Q. Effect of UV-B radiation on the growth and photosynthesis of cucumber (Cucumis sativus L.) seedlings. Acta Agric. Boreali-Sin. 2006, 21, 79-82.

36. Rybus-Zając, M.; Kubiś, J. Effect of UV-B radiation on antioxidative enzyme activity in cucumber cotyledons. Acta Biol. Crac. Ser. Bot. 2010, 52, 97-102. [CrossRef]

37. Liu, P.; Li, Q.; Li, Y.; Yu, H.; Jiang, W. Effect of UV-B radiation treatments on growth, physiology and antioxidant systems of cucumber seedlings in artificial climate chamber. Nongye Gongcheng Xuebao/Trans. Chin. Soc. Agric. Eng. 2017, 33, 181-186.

38. Darras, A.I.; Tsikaloudakis, G.; Lycoskoufis, I.; Dimitriadis, C.; Karamousantas, D. Low doses of UV-C irradiation affects growth, fruit yield and photosynthetic activity of tomato plants. Sci. Hortic. 2020, 267, 109357. [CrossRef]

39. Darras, A.I.; Demopoulos, V.; Tiniakou, C. UV-C irradiation induces defence responses and improves vase-life of cut gerbera flowers. Postharvest Biol. Technol. 2012, 64, 168-174. [CrossRef]

40. Darras, A.I.; Bali, I.; Argyropoulou, E. Disease resistance and growth responses in Pelargonium $\times$ hortorum plants to brief pulses of UV-C irradiation. Sci. Hortic. (Amst.) 2015, 181, 95-101. [CrossRef]

41. Darras, A.I.; Vlachodimitropoulou, A.; Dimitriadis, C. Regulation of corm sprouting, growth and flowering of pot Freesia hybrida L. plants by cold and UV-C irradiation forcing. Sci. Hortic. (Amst.) 2019, 252, 110-112. [CrossRef]

42. Bridgen, M. Using ultraviolet-c light as a plant growth regulator@. Acta Hortic. 2015, 1085, 167-169. [CrossRef]

43. Vàsquez, H.; Ouhibi, C.; Lizzi, Y.; Azzouz, N.; Forges, M.; Bardin, M.; Nicot, P.; Urban, L.; Aarrouf, J. Pre-harvest hormetic doses of UV-C radiation can decrease susceptibility of lettuce leaves (Lactuca sativa L.) to Botrytis cinerea L. Sci. Hortic. (Amst.) 2017, 222, 32-39. [CrossRef]

44. de Oliveira, I.R.; Crizel, G.R.; Severo, J.; Renard, C.M.G.C.; Chaves, F.C.; Rombaldi, C.V. Preharvest UV-C radiation influences physiological, biochemical, and transcriptional changes in strawberry cv. Camarosa. Plant Physiol. Biochem. 2016, 108, 391-399. [CrossRef] [PubMed]

45. Götz, M.; Albert, A.; Stich, S.; Heller, W.; Scherb, H.; Krins, A.; Langebartels, C.; Seidlitz, H.K.; Ernst, D. PAR modulation of the UV-dependent levels of flavonoid metabolites in Arabidopsis thaliana (L.) Heynh. leaf rosettes: Cumulative effects after a whole vegetative growth period. Protoplasma 2010, 243, 95-103. [CrossRef] [PubMed] 
46. Lee, M.J.; Son, J.E.; Oh, M.M. Growth and phenolic content of sowthistle grown in a closed-type plant production system with a UV-A or UV-B lamp. Hortic. Environ. Biotechnol. 2013, 54, 492-500. [CrossRef]

47. Lee, M.J.; Son, J.E.; Oh, M.M. Growth and phenolic compounds of Lactuca sativa L. grown in a closed-type plant production system with UV-A, -B, or -C lamp. J. Sci. Food Agric. 2014, 94, 197-204. [CrossRef] [PubMed]

48. Wang, H.; Gui, M.; Tian, X.; Xin, X.; Wang, T.; Li, J. Effects of UV-B on vitamin C, phenolics, flavonoids and their related enzyme activities in mung bean sprouts (Vigna radiata). Int. J. Food Sci. Technol. 2017, 52, 827-833. [CrossRef]

49. Tsurunaga, Y.; Takahashi, T.; Katsube, T.; Kudo, A.; Kuramitsu, O.; Ishiwata, M.; Matsumoto, S. Effects of UV-B irradiation on the levels of anthocyanin, rutin and radical scavenging activity of buckwheat sprouts. Food Chem. 2013, 141, 552-556. [CrossRef]

50. Castagna, A.; Chiavaro, E.; Dall'Asta, C.; Rinaldi, M.; Galaverna, G.; Ranieri, A. Effect of postharvest UV-B irradiation on nutraceutical quality and physical properties of tomato fruits. Food Chem. 2013, 137, 151-158. [CrossRef]

51. Namlı, S.; Işıkalan, Ç.; Akbaş, F.; Toker, Z.; Tilkat, E.A. Effects of UV-B radiation on total phenolic, flavonoid and hypericin contents in Hypericum retusum Aucher grown under in vitro conditions. Nat. Prod. Res. 2014, 28, 2286-2292. [CrossRef]

52. Rozema, J.; Björn, L.; Bornman, J.; Gaberščik, A.; Häder, D.-P.; Trošt, T.; Germ, M.; Klisch, M.; Gröniger, A.; Sinha, R.; et al. The role of UV-B radiation in aquatic and terrestrial ecosystems-An experimental and functional analysis of the evolution of UV-absorbing compounds. J. Photochem. Photobiol. B Biol. 2002, 66, 2-12. [CrossRef]

53. Cerovic, Z.G.; Ounis, A.; Cartelat, A.; Latouche, G.; Goulas, Y.; Meyer, S.; Moya, I. The use of chlorophyll fluorescence excitation spectra for the non-destructive in situ assessment of UV-absorbing compounds in leaves. Plant. Cell Environ. 2002, 25, 1663-1676. [CrossRef]

54. Kotilainen, T.; Tegelberg, R.; Julkunen-Tiitto, R.; Lindfors, A.; Aphalo, P.J. Metabolite specific effects of solar UV-A and UV-B on alder and birch leaf phenolics. Glob. Chang. Biol. 2008, 14, 1294-1304. [CrossRef]

55. Kotilainen, T.; Venäläinen, T.; Tegelberg, R.; Lindfors, A.; Julkunen-Tiitto, R.; Sutinen, S.; O’Hara, R.B.; Aphalo, P.J. Assessment of UV biological spectral weighting functions for phenolic metabolites and growth responses in silver birch seedlings. Photochem. Photobiol. 2009, 85, 1346-1355. [CrossRef] [PubMed]

56. Ibdah, M.; Krins, A.; Seidlitz, H.K.; Heller, W.; Strack, D.; Vogt, T. Spectral dependence of flavonol and betacyanin accumulation in Mesembryanthemum crystallinum under enhanced ultraviolet radiation. Plant. Cell Environ. 2002, 25, 1145-1154. [CrossRef]

57. Morales, L.O.; Tegelberg, R.; Brosche, M.; Keinanen, M.; Lindfors, A.; Aphalo, P.J. Effects of solar UV-A and UV-B radiation on gene expression and phenolic accumulation in Betula pendula leaves. Tree Physiol. 2010, 30, 923-934. [CrossRef]

58. Lavola, A.; Aphalo, P.J.; Lahti, M.; Julkunen-Tiitto, R. Nutrient availability and the effect of increasing UV-B radiation on secondary plant compounds in Scots pine. Environ. Exp. Bot. 2003, 49, 49-60. [CrossRef]

59. Nenadis, N.; Llorens, L.; Koufogianni, A.; Díaz, L.; Font, J.; Gonzalez, J.A.; Verdaguer, D. Interactive effects of UV radiation and reduced precipitation on the seasonal leaf phenolic content/composition and the antioxidant activity of naturally growing Arbutus unedo plants. J. Photochem. Photobiol. B Biol. 2015, 153, 435-444. [CrossRef]

60. Trivellini, A.; Lucchesini, M.; Maggini, R.; Mosadegh, H.; Villamarin, T.S.S.; Vernieri, P.; Mensuali-Sodi, A.; Pardossi, A. Lamiaceae phenols as multifaceted compounds: Bioactivity, industrial prospects and role of "positive-stress". Ind. Crops Prod. 2016, 83, 241-254. [CrossRef]

61. Schreiner, M.; Martínez-Abaigar, J.; Glaab, J.; Jansen, M. UV-B induced secondary plant metabolites: Potential benefits for plant and human health. Optik Photonik 2014, 9, 34-37. [CrossRef]

62. Murthy, H.N.; Lee, E.-J.; Paek, K.Y. Production of secondary metabolites from cell and organ cultures: Strategies and approaches for biomass improvement and metabolite accumulation. Plant Cell Tissue Organ Cult. 2014, 118, 1-16. [CrossRef]

63. Lee, C.J.; Chen, L.G.; Chang, T.L.; Ke, W.M.; Lo, Y.F.; Wang, C.C. The correlation between skin-care effects and phytochemical contents in Lamiaceae plants. Food Chem. 2011, 124, 833-841. [CrossRef]

64. Ramos, M.; Jiménez, A.; Peltzer, M.; Garrigós, M.C. Characterization and antimicrobial activity studies of polypropylene films with carvacrol and thymol for active packaging. J. Food Eng. 2012, 109, 513-519. [CrossRef]

65. Khaled-Khodja, N.; Boulekbache-Makhlouf, L.; Madani, K. Phytochemical screening of antioxidant and antibacterial activities of methanolic extracts of some Lamiaceae. Ind. Crops Prod. 2014, 61, 41-48. [CrossRef]

66. Bertoli, A.; Lucchesini, M.; Mensuali-Sodi, A.; Leonardi, M.; Doveri, S.; Magnabosco, A.; Pistelli, L. Aroma characterisation and UV elicitation of purple basil from different plant tissue cultures. Food Chem. 2013, 141, 776-787. [CrossRef]

67. Ghasemzadeh, A.; Ashkani, S.; Baghdadi, A.; Pazoki, A.; Jaafar, H.; Rahmat, A. Improvement in flavonoids and phenolic acids production and pharmaceutical quality of sweet basil (Ocimum basilicum L.) by ultraviolet-B irradiation. Molecules 2016, 21, 1203. [CrossRef] [PubMed]

68. Escobar, A.L.; de Oliveira Silva, F.M.; Acevedo, P.; Nunes-Nesi, A.; Alberdi, M.; Reyes-Díaz, M. Different levels of UV-B resistance in Vaccinium corymbosum cultivars reveal distinct backgrounds of phenylpropanoid metabolites. Plant Physiol. Biochem. 2017, 118, 541-550. [CrossRef]

69. Mosadegh, H.; Trivellini, A.; Ferrante, A.; Lucchesini, M.; Vernieri, P.; Mensuali, A. Applications of UV-B lighting to enhance phenolic accumulation of sweet basil. Sci. Hortic. (Amst.) 2018, 229, 107-116. [CrossRef]

70. Von Lintig, J.; Welsch, R.; Bonk, M.; Giuliano, G.; Batschauer, A.; Kleinig, H. Light-dependent regulation of carotenoid biosynthesis occurs at the level of phytoene synthase expression and is mediated by phytochrome in Sinapis alba and Arabidopsis thaliana seedlings. Plant J. 1997, 12, 625-634. [CrossRef] 
71. Abeles, F.B.; Morgan, P.W.; Saltveit, M.E. Ethylene in Plant Biology, 2nd ed.; Academic Press: New York, NY, USA, 1992.

72. A.-H.-Mackerness, S.; Surplus, S.L.; Blake, P.; John, C.F.; Buchanan-Wollaston, V.; Jordan, B.R.; Thomas, B. Ultraviolet-B-induced stress and changes in gene expression in Arabidopsis thaliana: Role of signalling pathways controlled by jasmonic acid, ethylene and reactive oxygen species. Plant. Cell Environ. 1999, 22, 1413-1423.

73. Nara, A.; Takeuchi, Y. Ethylene evolution from tobacco leaves irradiated with UV-B. J. Plant Res. 2002, 115, 247-253. [CrossRef]

74. Predieri, S. Influence of UV-B radiation on membrane lipid composition and ethylene evolution in "Doyenne d'Hiver" pear shoots grown in vitro under different photosynthetic photon fluxes. Environ. Exp. Bot. 1995, 35, 151-160. [CrossRef]

75. Giuntini, D.; Graziani, G.; Lercari, B.; Fogliano, V.; Soldatini, G.F.; Ranieri, A. Changes in carotenoid and ascorbic acid contents in fruits of different tomato genotypes related to the depletion of UV-B radiation. J. Agric. Food Chem. 2005, 53, 3174-3181. [CrossRef] [PubMed]

76. Becatti, E.; Petroni, K.; Giuntini, D.; Castagna, A.; Calvenzani, V.; Serra, G.; Mensuali-Sodi, A.; Tonelli, C.; Ranieri, A. Solar UV-B radiation influences carotenoid accumulation of tomato fruit through both ethylene-dependent and -independent mechanisms. J. Agric. Food Chem. 2009, 57, 10979-10989. [CrossRef] [PubMed]

77. Hectors, K.; Prinsen, E.; De Coen, W.; Jansen, M.A.K.; Guisez, Y. Arabidopsis thaliana plants acclimated to low dose rates of ultraviolet $\mathrm{B}$ radiation show specific changes in morphology and gene expression in the absence of stress symptoms. New Phytol. 2007, 175, 255-270. [CrossRef] [PubMed]

78. Wang, Y.; Zhou, B.; Sun, M.; Li, Y.; Kawabata, S. UV-A light induces anthocyanin biosynthesis in a manner distinct from synergistic blue + UV-B light and UV-A/blue light responses in different parts of the hypocotyls in turnip seedlings. Plant Cell Physiol. 2012, 53, 1470-1480. [CrossRef] [PubMed]

79. Su, N.; Lu, Y.; Wu, Q.; Liu, Y.; Xia, Y.; Xia, K.; Cui, J. UV-B-induced anthocyanin accumulation in hypocotyls of radish sprouts continues in the dark after irradiation. J. Sci. Food Agric. 2016, 96, 886-892. [CrossRef]

80. Solovchenko, A. Significance of skin flavonoids for UV-B-protection in apple fruits. J. Exp. Bot. 2003, 54, 1977-1984. [CrossRef]

81. Park, W.T.; Kim, Y.B.; Seo, J.M.; Kim, S.-J.; Chung, E.; Lee, J.-H.; Park, S.U. Accumulation of anthocyanin and associated gene expression in radish sprouts exposed to light and methyl jasmonate. J. Agric. Food Chem. 2013, 61, 4127-4132. [CrossRef]

82. Su, N.; Wu, Q.; Liu, Y.; Cai, J.; Shen, W.; Xia, K.; Cui, J. Hydrogen-rich water reestablishes ROS homeostasis but exerts differential effects on anthocyanin synthesis in two varieties of radish sprouts under UV-A irradiation. J. Agric. Food Chem. 2014, 62, 6454-6462. [CrossRef]

83. Bruce, T.J.A.; Matthes, M.C.; Napier, J.A.; Pickett, J.A. Stressful "memories" of plants: Evidence and possible mechanisms. Plant Sci. 2007, 173, 603-608. [CrossRef]

84. Mata, D.A.; Botto, J.F. Manipulation of light environment to produce high-quality poinsettia plants. HortScience 2009, 44, 702-706. [CrossRef]

85. Qian, M.; Rosenqvist, E.; Flygare, A.-M.; Kalbina, I.; Teng, Y.; Jansen, M.A.K.; Strid, Å. UV-A light induces a robust and dwarfed phenotype in cucumber plants (Cucumis sativus L.) without affecting fruit yield. Sci. Hortic. (Amst.) 2020, 263, 109110. [CrossRef]

86. Morel, P.; Crespel, L.; Galopin, G.; Moulia, B. Effect of mechanical stimulation on the growth and branching of garden rose. Sci. Hortic. (Amst.) 2012, 135, 59-64.

87. Börnke, F.; Rocksch, T. Thigmomorphogenesis-Control of plant growth by mechanical stimulation. Sci. Hortic. (Amst.) 2018, 234, 344-353. [CrossRef]

88. Sánchez-Blanco, M.J.; Ortuño, M.F.; Bañon, S.; Álvarez, S. Deficit irrigation as a strategy to control growth in ornamental plants and enhance their ability to adapt to drought conditions. J. Hortic. Sci. Biotechnol. 2019, 94, 137-150. [CrossRef]

89. Kakani, V.G.; Reddy, K.R.; Zhao, D.; Sailaja, K. Field crop responses to ultraviolet-B radiation: A review. Agric. For. Meteorol. 2003, 120, 191-218. [CrossRef]

90. Wargent, J.J.; Taylor, A.; Paul, N.D. UV supplementation for growth regulation and disease control. Acta Hortic. 2006, 711, 333-338. [CrossRef]

91. Kuhlmann, F.; Müller, C. Development-dependent effects of UV radiation exposure on broccoli plants and interactions with herbivorous insects. Environ. Exp. Bot. 2009, 66, 61-68. [CrossRef]

92. Singh, S.; Kumari, R.; Agrawal, M.; Agrawal, S.B. Modification in growth, biomass and yield of radish under supplemental UV-B at different NPK levels. Ecotoxicol. Environ. Saf. 2011, 74, 897-903. [CrossRef]

93. Torre, S.; Roro, A.G.; Bengtsson, S.; Mortensen, L.M.; Solhaug, K.A.; Gislerød, H.R.; Olsen, J.E. Control of plant morphology by UV-B and UV-B-temperature interactions. Acta Hortic. 2012, 956, 207-214. [CrossRef]

94. Liu, B.; Liu, X.; Li, Y.-S.; Herbert, S.J. Effects of enhanced UV-B radiation on seed growth characteristics and yield components in soybean. F. Crop. Res. 2013, 154, 158-163. [CrossRef]

95. Sakalauskaitè, J.; Viskelis, P.; Dambrauskienė, E.; Sakalauskienė, S.; Samuolienė, G.; Brazaitytè, A.; Duchovskis, P.; Urbonavičienė, D. The effects of different UV-B radiation intensities on morphological and biochemical characteristics in Ocimum basilicum L. J. Sci. Food Agric. 2013, 93, 1266-1271. [CrossRef] [PubMed]

96. Biswas, D.K.; Jansen, M.A.K. Natural variation in UV-B protection amongst Arabidopsis thaliana accessions. Emir. J. Food Agric. 2012, 24, 621-631. [CrossRef] 
97. Demkura, P.V.; Ballaré, C.L. UVR8 mediates UV-B-induced Arabidopsis defense responses against Botrytis cinerea by controlling sinapate accumulation. Mol. Plant 2012, 5, 642-652. [CrossRef] [PubMed]

98. Demkura, P.V.; Abdala, G.; Baldwin, I.T.; Ballaré, C.L. Jasmonate-dependent and -independent pathways mediate specific effects of solar ultraviolet B radiation on leaf phenolics and antiherbivore defense. Plant Physiol. 2010, 152, 1084-1095. [CrossRef]

99. Ballaré, C.L.; Mazza, C.A.; Austin, A.T.; Pierik, R. Canopy light and plant health. Plant Physiol. 2012, 160, 145-155. [CrossRef]

100. Lloyd, A.J.; Allwood, J.W.; Winder, C.L.; Dunn, W.B.; Heald, J.K.; Cristescu, S.M.; Sivakumaran, A.; Harren, F.J.M.; Mulema, J.; Denby, K.; et al. Metabolomic approaches reveal that cell wall modifications play a major role in ethylene-mediated resistance against Botrytis cinerea. Plant J. 2011, 67, 852-868. [CrossRef]

101. Hoffmann-Campo, C.B.; Harborne, J.B.; McCaffery, A.R. Pre-ingestive and post-ingestive effects of soya bean extracts and rutin on Trichoplusiani growth. Entomol. Exp. Appl. 2001, 98, 181-194. [CrossRef]

102. Farhoudi, R.; Saeedipour, S.; Mohammadreza, D. The effect of $\mathrm{NaCl}$ seed priming on salt tolerance, antioxidant enzyme activity, proline and carbohydrate accumulation of muskmelon (Cucumis melo L.) under saline condition. Afr. J. Agric. Res. 2011, 6, 1363-1370.

103. Falguera, V.; Garvín, A.; Garza, S.; Pagán, J.; Ibarz, A. Effect of UV-vis photochemical processing on pear juices from six different varieties. Food Bioprocess Technol. 2014, 7, 84-92. [CrossRef]

104. Ouhibi, C.; Attia, H.; Rebah, F.; Msilini, N.; Chebbi, M.; Aarrouf, J.; Urban, L.; Lachaal, M. Salt stress mitigation by seed priming with UV-C in lettuce plants: Growth, antioxidant activity and phenolic compounds. Plant Physiol. Biochem. 2014, 83, 126-133. [CrossRef]

105. Jansen, M.A.K.; Hectors, K.; O’Brien, N.M.; Guisez, Y.; Potters, G. Plant stress and human health: Do human consumers benefit from UV-B acclimated crops? Plant Sci. 2008, 175, 449-458. [CrossRef]

106. Lu, Y.; Dong, W.; Alcazar, J.; Yang, T.; Luo, Y.; Wang, Q.; Chen, P. Effect of preharvest CaCl2 spray and postharvest UV-B radiation on storage quality of broccoli microgreens, a richer source of glucosinolates. J. Food Compos. Anal. 2018, 67, 55-62. [CrossRef]

107. Liu, C.; Han, X.; Cai, L.; Lu, X.; Ying, T.; Jiang, Z. Postharvest UV-B irradiation maintains sensory qualities and enhances antioxidant capacity in tomato fruit during storage. Postharvest Biol. Technol. 2011, 59, 232-237. [CrossRef]

108. Stevens, C.; Liu, J.; Khan, V.A.; Lu, J.Y.; Kabwe, M.K.; Wilson, C.L.; Igwegbe, E.C.K.; Chalutz, E.; Droby, S. The effects of low-dose ultraviolet light-C treatment on polygalacturonase activity, delay ripening and Rhizopus soft rot development of tomatoes. Crop Prot. 2004, 23, 551-554. [CrossRef]

109. Park, M.-H.; Kim, J.-G. Low-dose UV-C irradiation reduces the microbial population and preserves antioxidant levels in peeled garlic (Allium sativum L.) during storage. Postharvest Biol. Technol. 2015, 100, 109-112. [CrossRef]

110. Artés, F.; Conesa, A.; Lopez-Rubira, V.; Artes-Hernandez, F. UV-C treatments for improving microbial quality in whole and minimally processed bell peppers. In The Use of $U V$ as a Postharvest Treatment: Status and Prospects; Ben-Yehoshua, S., D'Hallewin, G., Erkan, M., Rodov, V., Lagunas, M., Eds.; Kros Ofset-Yakup Kublay: Antalya, Turkey, 2006; pp. 12-17.

111. Bintsis, T.; Litopoulou-Tzanetaki, E.; Robinson, R.K. Existing and potential applications of ultraviolet light in the food industry-A critical review. J. Sci. Food Agric. 2000, 80, 637-645. [CrossRef]

112. Gardner, D.W.M.; Shama, G. Modeling UV-induced inactivation of microorganisms on surfaces. J. Food Prot. 2000, 63, 63-70. [CrossRef]

113. Mercier, J.; Ben-Yehoshua, S. UV irradiation, biological agents, and natural compounds for controlling postharvest decay in fresh fruits and vegetables. In Environmentally Friendly Technologies for Agricultural Produce Quality; CRC Press: Boca Raton, FL, USA, 2005; pp. 265-299.

114. Erkan, M.; Wang, C.Y.; Krizek, D.T. UV-C irradiation reduces microbial populations and deterioration in Cucurbita pepo fruit tissue. Environ. Exp. Bot. 2001, 45,1-9. [CrossRef]

115. Liu, J.; Stevens, C.; Khan, V.A.; Lu, J.Y.; Wilson, C.L.; Adeyeye, O.; Kabwe, M.K.; Pusey, P.L.; Chalutz, E.; Sultana, T.; et al. Application of ultraviolet-C light on storage rots and ripening of tomatoes. J. Food Prot. 1993, 56, 868-873. [CrossRef]

116. Stevens, C.; Khan, V.A.; Lu, J.Y.; Wilson, C.L.; Chalutz, E.; Droby, S.; Kabwe, M.K.; Haung, Z.; Adeyeye, O.; Pusey, L.P.; et al. Induced resistance of sweetpotato to Fusarium root rot by UV-C hormesis. Crop Prot. 1999, 18, 463-470. [CrossRef]

117. Fonseca, J.M.; Rushing, J.W. Effect of ultraviolet-C light on quality and microbial population of fresh-cut watermelon. Postharvest Biol. Technol. 2006, 40, 256-261. [CrossRef]

118. Manzocco, L.; Da Pieve, S.; Bertolini, A.; Bartolomeoli, I.; Maifreni, M.; Vianello, A.; Nicoli, M.C. Surface decontamination of fresh-cut apple by UV-C light exposure: Effects on structure, colour and sensory properties. Postharvest Biol. Technol. 2011, 61, 165-171. [CrossRef]

119. González-Aguilar, G.A.; Zavaleta-Gatica, R.; Tiznado-Hernández, M.E. Improving postharvest quality of mango ‘Haden' by UV-C treatment. Postharvest Biol. Technol. 2007, 45, 108-116. [CrossRef]

120. Lante, A.; Tinello, F.; Nicoletto, M. UV-A light treatment for controlling enzymatic browning of fresh-cut fruits. Innov. Food Sci. Emerg. Technol. 2016, 34, 141-147. [CrossRef]

121. Degl'Innocenti, E.; Guidi, L.; Pardossi, A.; Tognoni, F. Biochemical study of leaf browning in minimally processed leaves of lettuce (Lactuca sativa L. var. acephala). J. Agric. Food Chem. 2005, 53, 9980-9984. [CrossRef] [PubMed]

122. Manzocco, L.; Quarta, B.; Dri, A. Polyphenoloxidase inactivation by light exposure in model systems and apple derivatives. Innov. Food Sci. Emerg. Technol. 2009, 10, 506-511. [CrossRef] 
123. Falguera, V.; Pagán, J.; Ibarz, A. Effect of UV irradiation on enzymatic activities and physicochemical properties of apple juices from different varieties. LWT Food Sci. Technol. 2011, 44, 115-119. [CrossRef]

124. Sampedro, F.; Fan, X. Inactivation kinetics and photoreactivation of vegetable oxidative enzymes after combined UV-C and thermal processing. Innov. Food Sci. Emerg. Technol. 2014, 23, 107-113. [CrossRef]

125. Manzocco, L.; Kravina, G.; Calligaris, S.; Nicoli, M.C. Shelf life modeling of photosensitive food: The case of colored beverages. J. Agric. Food Chem. 2008, 56, 5158-5164. [CrossRef] 